\title{
An Assessment of Electronic-Auditing and Economic Value of the Nigerian Listed Companies
}

\author{
Rebecca Deborah Benjamin*1, Samson Adebolu Adegbite ${ }^{2}$, Appolos Nwabuisi Nwaobia ${ }^{1}$, \\ Isoken Joy Adekunle ${ }^{3}$ \\ ${ }^{1}$ Department of Accounting, Babcock University, Ilishan-Remo Ogun State, Nigeria \\ ${ }^{2}$ Department of Accounting, Osun State University, Osogbo, Nigeria \\ ${ }^{3}$ Department of Accounting, Crescent University, Abeokuta, Ogun State, Nigeria
}

\begin{abstract}
The bid for an internal auditor to remain relevant in a technologically driven business and add value in a modern and complex global business environment remains a challenge in the accounting profession in Nigeria. This study evaluated the effect of electronic-auditing by internal auditors for the improved economic value of listed companies in Nigeria. The study adopted a survey research design. The sample size of the study consisted of 24 companies selected from the eleven industrial subsectors (Agriculture, Conglomerates, Construction, Consumer goods, financial services, Services, Health Care, ICT, Industrial goods, Natural Resources and Oil and Gas sectors) among the 161 listed companies on the Nigerian Stock Exchange as at 30 November 2019. The sample frame of this study is 5,012 respondent units, and the sample size is 501, comprising 401 internal auditors and 100 top management staff. A validated structured questionnaire with a five-point Likert-type scale was administered, and $78.443 \%$ response rate was achieved. Random sampling technique was adopted in the selection of the 24 companies with about two companies representing each sector. The research instrument was subjected to content validity and reliability test, which yielded Cronbach's alpha coefficient value of 0.80 . The findings revealed that electronic-auditing had a positive and significant effect on the economic value of listed companies in Nigeria ( $\beta=$ $0.061, \mathrm{t}(393)=4.396, \mathrm{p}<0.05)$. The study concluded that possession and utilisation of electronic-auditing skills are essential for internal auditors who must have the requisite expertise to analyse the risks that advance technology requires to be able to add economic value in an organisation.
\end{abstract}

Keywords: Economic value, electronic-auditing, information technology, Internal auditor, pandemic.

JEL Classification: M42

Paper Type: Research

*Corresponding author: E-mail: benjaminr@babcock.edu.ng 


\section{INTRODUCTION}

The growth and expansion of businesses where an increased number of persons carry out the operation of an organisation necessitated the need for an independent group of persons to verify processes in order to reduce record-keeping error and fraud within an organisation, and this led to the usual demand for both internal and external auditing services. Nevertheless, the emergence and increasing rate of electronic and mobile business transactions without facial contact across the globe has transformed ecommerce and also brought about changes in the roles and processes of internal auditors within an organisation. However, despite the explosion in technological advancement, internal auditor still focuses on traditional application control and security system. There is a need to investigate why internal auditors still do little work related to IT assets safeguard and a need to enhance their knowledge in computerised information systems (Abu-Musa, 2018). Haislip, Peters and Richardson (2016) revealed that firms that switched to auditors with more excellent IT expertise have a greater chance of material weakness remediation within one year of reporting control weaknesses. This implies that IT expertise attracts clients and thus underscores the great importance of IT competence to auditors. Internal auditing, specifically, is expected to add value and enhance corporate performance (Abu-Musa, 2018). The reports of corporate scandals and the corresponding audit failures across the globe made the public and the audit market lose confidence in the audit profession.

Studies such as AbdulGaniyy (2013); Onoja and Haruna (2015); and Hickman (2017) reveal that audit failure has resulted in the collapse of business organisations, loss of investments and crisis of confidence in the work of auditors. Also, studies of Salehi and Alipour, 2010); Shahimi, Mahzan and Zulkifli (2016) noted that internal auditors are well qualified in their relevant and related experiences but lack information technology knowledge and tools or skill required to simplify their work. They could not adequately cope with the increasing computerisation of information system because they are still using the same manual techniques when auditing computerised based organisations.

Internal auditing is an independent, objective assurance and consulting activity intended to add value to an organisation (IIA, 2000). Internal auditors are to assist an organisation in improving operations in order to achieve its objectives and bring about an orderly, disciplined method of evaluating and improving the effectiveness of risk management, control and governance processes (Wen-Hsien, Hui-Chiao, Jui-Chu, \& Hsiu-Li, 2017). It is therefore imperative for internal auditors to ensure careful use of an organisation's resources to save expenses, time and effort that would add economic value to foster sustainable growth. In government, the emphasis had shifted from expenditure control towards value for money and the need for maximum utilisation of economic resources (Nwosu, 2016). The reported corporate failures all over the world in the last two decades have brought internal auditing to a focal point both in practice and academic environs. Nwosu (2016) submitted that the expanding role of auditors requires new techniques in the discharge of their duties to address environmental changes and challenges. This suggested that when auditors know the current state of the profession, where it is heading to, then they can be better prepared for the future (Lombard, Bloch \& Vasarhely, 2014).

Akinnaso, (2017) has noted information technology to be a driving force of every activity in an organisation as we now have E-commerce, E-health, E-learning, E-banking and now E-Governance, that is the application of Information and Communication 
Technologies (ICTs) in governance activities. According to Abiola (2014), information and communication technology tools and procedures are becoming inseparable in the organisational process and controls. The recent drive for paperless society whereby most business transactions are concluded online demands paperless audit in response and audit clients are increasingly shifting to a paperless system. Different audit software is being developed to enable auditors to keep pace with the prevailing business environment (Schwab, 2016). Onuigbo and Ene (2015) noted that technological advances have improved ways that people perform their daily activities. Hence auditors have to acquire knowledge in audit software as their primary audit tool and be able to obtain audit evidence electronically. Therefore, information technology has impacted every audit process from audit planning, testing and documentation. Henderson, Davis and Lapke (2013) and Moorthy, Mohamed, Gopalan and San (2011) submitted that there is a positive relationship between information technology usage and internal audit effectiveness and as such effective internal auditing depends heavily on the use of information technology while the study further revealed that the internal auditors lacked required information technology knowledge.

AbdulGaniyy (2013) submitted that as the business environment gets more globalised and complex, internal auditing expertise would be essential in maintaining audit quality within an organisation. Globalisation, change in economic conditions and the business environment have remained the primary driving force behind the increasing expansion of the audit market. Dhumal (2015) established that we are in the era of Information and Communication Technology. Therefore e-governance performance should be increased for better and adequate implementation of decision making. E-governance is the application of ICT to governance for a sustainable framework (Izhar, Xue, Abdullah, Ali, Shah \& Ilyas, 2017). Schwab (2016) posited that we are in the Fourth Industrial Revolution, which characterises by a range of new technologies. According to Dzuranin and Malaescu (2016), information technology has revolutionised business and become a driving force for future development.

In Nigeria, the urgent migration to embrace the use of information technology is now more glaring due to outbreak of Coronavirus pandemic that has crumbled economic activities in the country such as the shutdown of business activities, disruption of business activities of small and medium scale enterprises and cut-off of the supply chain of manufacturing companies. AbdurRaheem (2020) documented the coping strategies for entrepreneurs and their implication on post-COVID-19 business which include widespread e-activities such as e-taxation, e-governance, e-commerce, e-banking, and e-learning increased relevance of ICT software and application; increased online social interaction; increased acceptance of online education and training for students and emergence of forced online communities.

Many studies have been carried out in the area of internal audit and corporate performance both in Nigeria and developed nations around the globe. Many of these studies focussed on internal audit function and effectiveness in an organisation, for example, internal audit techniques and fraud prevention (Onoja \& Haruna, 2015); the role of internal audit in fraud prevention and detection (Petrascu \& Tieanu, 2014) and effect of internal audit function on the financial performance (Ejoh \& Ejom, 2014). However, literature has not revealed significant studies in the area of electronic auditing and the economic value of an organisation. 
One contribution of our current study is its timeliness and relevance in filling this identified gap in the literature. The study conducts an evaluation of electronic auditing by internal auditors for the improved economic value of listed companies in Nigeria, considering the explosion in information technology, the changing role of internal auditors and recent corporate failures. It investigates the value-adding skills and competencies required of internal auditors to meet the expectation of users in a dynamic business environment.

The rest of this paper is organised as follows: in section 2, we review extant literature and highlight the theoretical underpinning for the study. Section 3 presents the methodology of the study, including the measurement of variables. Section 4 presents the empirical analyses, results and discussion, while we conclude in section 5.

\section{REVIEW OF LITERATURE 2.1 Conceptual Review}

Studies have reported the emergence of information technology to accounting processes, and how it has changed the way and manner in which accounting data were stored, retrieved and processed and how these resulted in the loss of audit trails on the part of auditors (Salehi \& Alipour, 2010). The new techniques lead to the introduction of new audit standards, and the process became different from traditional audit, thus the changing roles of internal auditors. Salehi and Alipour (2010) further submitted that information technology causes remarkable changes in internal auditing and affirmed that information technology has revolutionised business and become a driving force for future development. Salehi and Husini (2011), in their study, submitted that internal auditing focuses on the technical and independent appraisal of economic activities within the organisation. Information technology favours some threat in the information technology environment in comparison to the manual environment. Therefore, for the internal auditor to mitigate these challenges, an internal auditor would need to focus on the internal control system of the organisation as administrative techniques of control would invariably change the nature of auditing.

Information technology is being seen as the application of technical information processes or method to achieve a task. At the same time, data analytics enable an auditor to interrogate the whole population of data instead of relying on the results of sampling a small portion of the data or information obtainable. Barac, Gammie, Howieson, and Van-Staden (2016) and Turley, Humphrey, Samwonova-Taddei, Siddiqui, Woods, Basioud, and Richard (2016) posited that advances in technology pose new challenges and risks both for the businesses and their auditor. An internal auditor must possess adequate expertise required to support the management of an organisation in achieving its objectives. Moorthy, Seetharaman, Mohamed, Gopalan, and San (2011) stress the importance of the role of internal auditor's information technology literacy and how it affects internal auditor activities in an organisation. The trend is towards the changing roles of internal auditors as technology, information system, electronic data processing has changed organisations' processes in the bid of promoting efficiency and helping decision-making processes. In this regard, Wen-Hsien, Hui-Chiao, Jui-Chu and Hsiu-Li (2017) in their study submitted that companies needed to enhance their internal auditors' information technology competence and implement enterprise risk management entirely in order to improve internal audit performance. 
Internal auditing involves a careful examination of the financial records or transactions of a business to ascertain that all due process has been adhered to as stipulated by the management. It is therefore expected that they should report to an audit committee composed of directors who are not a part of management to ensure their independence because the internal auditors typically report on some part of management's performance (Institute of Internal Auditors, 2000). Different researchers have given internal audit various definitions over the years across the globe. In most business organisations today, the internal auditing function functions both as internal control reviewer and business risk assessor as a pro-active measure. Ferdinand and Mahzan (2013) argued that internal auditing is typically broader in scope or coverage than the auditing carried out by the external auditors when they audit financial statements, which is a statutory audit. The Institute of Internal Auditors (2000) posited that internal auditors have the advantage to assist the management in achieving their goal because they are part of the system they audit. Also, they participate in the day to day activities of the organisation. They can prompt the management of anything that constitutes a variance to the organisational goals. Internal auditors would be more helpful to the management in preventing and detecting fraud. Also, the Institute of Internal Auditors (2000) defined internal auditor as an employee of the organisation saddled with the responsibility to carry out the auditing function for the company.

Economic value in this study is concerned with the monetary value for the expenses incurred concerning the valued added to the organisation. Economic value is one of the components of value for money audit. According to Shahimi, Mahzan and Zulkifli, (2016) from the stewardship perspective, internal auditors could support the board and management team through their consulting role. They are expected to provide advice on business improvement or further investment opportunities. Internal audit is argued to be an enabler of business performance and provider of knowhow that can support the business objective. This is on the premise that internal auditors possess detailed knowledge of the organisation; thus, they can position themselves as consultants when there is a necessity to impart the collective information. Internal auditors occupy advisory role to the organisation on financial matters and otherwise and thus, add economic value on the long run. Dibia (2016), in his study, submitted that internal auditing includes providing internal consulting service to all levels of the organisation in terms of training, advice and professional counsels.

Unegbu and Kida (2011) defined an internal audit as a feature of the internal control system established by the management of an organisation in order to ensure proper compliance with the specific policies and procedures in order to achieve management objectives. The internal auditor ensures compliance with the laid down rules, procedures, regulations and guidelines of the organisation. The internal audit function is considered an essential component in ensuring good corporate governance. According to Ali, Sahdan, Rahim and Gloeck (2012) in public limited liability companies and private organisations, internal audit is seen to assist the organisation in enhancing the performance of their activities. This position is the reason why the management of an organisation usually deliberately establishes the internal audit department.

Ali (2013) posited that the internal audit function holds a high potential for promoting accountability and enhancing government performance in the public sector. Strategic measures on internal arrangement include requiring the setting up of internal audit units, the establishment of standards for the professional conduct of internal audit engagement, training for resource allotment; intensifying reporting arrangements and 
lengthening mandates to make auditors accountable for performance assessment and considering internal control as a vital tool of accountability within the organisation. Shahimi, Mahzan and Zulkifli (2016) asserted that the best practice for internal auditors is the collaboration of internal audit and information technology departments in an organisation in order to be able to mitigate information system risk proactively. It has been observed that computer fraud is easy to commit but challenging to prevent and therefore, the auditors are to define their responsibility for computer fraud. As ACFE (2010) put it, in the current dispensation of technological advancement and considering the height that fraud has grown, the accounting and auditing profession alone cannot tackle the challenges.

\subsection{Theoretical Underpinning}

The underpinning theory for this study is the theory of inspired confidence. Theory of inspired confidence was developed in the 1920s by Professor Theodore Limperg. He submitted that the demand for audit services is the direct consequence of the involvement of outside stakeholders in the company. This is also referred to as the theory of rational expectations (Limperg, 1932). The theory is based on the demand and the supply for audit services. The assumption is that the demand for audit services is the direct consequence of the contribution of third parties in the company. These parties require accountability from the management in return for their funds in the company. The theory submitted that accountability is achieved through the issuance of periodic financial reports to the various stakeholders. However, since the information provided by the management may be influenced, and outside parties have no direct means of monitoring, an audit is essential to assure the reliability of this information.

The relevance of this theory to our study is the supply of audit assurance as Limperg (1932) suggests should continuously endeavour to meet the public expectations because it is the credibility of the work of an auditor that inspires the confidence of the various users of the financial report of an organisation. The responsibility then lies on the internal auditor to ensure the credibility of their work which would translate to improved corporate performance of the organisation. In support, Flint (1980) submitted that even though Limperg was writing 50 years earlier in a different world, different economic and social conditions, with different ideas of accountability than those of today and government, state, public economic and financial activity and involvement being different, that the theoretical framework from which he was writing was still sound and relevant because there are systematic and logical relationships in the elements of the audit process which are enduring and universal. Also, in 1985, Limperg Institute (1985, p.3) further expanded the theory of inspired confidence by connecting the community needs for the reliability of financial information to the ability of audit techniques to meet these needs. It stressed the development of the community need and the techniques of auditing with time. The Institute further submitted that changes in need of the community and the changes in the auditing techniques result in a change in the auditor's function.

However, Carmichael (2004, p.12a) argued that the theory of inspired confidence does not prescribe definite rules about the behaviour of the auditor in each particular case, but that it is a principle-based approach. Carmichael (2004) in the Public Company Accounting Oversight Board (PCAOB) and the social responsibility of auditors 2004 focused on the role of the PCAOB and its performance in restoring the confidence of investors in the independent auditors of public companies. PCAOB position disagrees with the Limperg's submission that when the confidence the society has in the 
effectiveness of the audit and the opinion of the audit is lost, then this could cast aspersion on the social usefulness of the audit. According to Carmichael (2004), the theory of Limperg is relevant in the phase of the development of the audit function on the premise that we have a particular need in our current environment to try to understand and appreciate the social significance of auditing and the implication concerning in which way an audit should be performed. However, Pathan (2009) reaffirmed that the inspired confidence theory is associated with the society's need for the dependability of commercial information to the capacity of audit and the board oversight to meet the needs. It further emphasised the improvement of the desires of the community and the procedures of auditing and oversight with time. It then implied that the function of the oversight bodies emanated from the confidence that the society places in the efficiency of the bodies (Lary \& Taylor, 2012).

Peltier-Rivest and Lanoue (2015) assert that the normative basis of the theory of inspired confidence is that the oversight bodies are obliged to carry out their work in such a way that they do not betray the anticipation of the stakeholders and the public. As such corporate board of directors and external auditors and by internal extension auditors, are expected to play their oversight role with professionalism such that the control of the stewardship of the organisation which is expected to lead to a well-managed organisation is maintained.

\subsection{Empirical Review}

Many studies on the relationship between the internal audit performance and effect of information technology on internal auditing cast aspersion on whether internal auditors have the necessary skills to recognise and analyse the risks that are continually advancing technology pose to the companies. In this light, Barac et al. (2016) in their study on auditor skills in a changing business world submitted that information technology is considered crucial to the quality of internal auditing in an organisation as advancement in technology poses new challenges and risks for both the businesses and their auditors.

In consonant, Wen-Hsien et al. (2017) in their study of the internal audit performance: the effectiveness of ERM and IT environment asserted that companies needed to enhance their internal auditors' information technology competence in order to boost internal audit performance. Obert and Munyunguma (2014) considered the influence of globalisation and changing role of internal auditor in monitoring organisational and financial activities of listed companies in Nigeria and concluded that internal auditors are to be concerned on both financial and non-financial activities of an organisation.

Dzuranin and Malaescu (2016) in their study on the current state and future direction for information technology audit: challenge and opportunities, in the bid to enhance the value of audit practitioner in line with emerging technologies, considered the role of information technology auditors in helping organisations meet compliance requirement ensuring that information systems add value to the organisation. In considering the future of information technology audit in a world of advanced analytical and emerging technologies, Barac et al. submitted that auditor faces challenges in terms of an increasing volume of data available coupled with changing technology. This suggested that information technology knowledge is germane for the relevancy of an auditor in a technologically driven business environment. 
Schwab (2016), the founder and executive chairman of the World Economic Forum in his address reported that the world is entering into the fourth industrial revolution which will be characterised by a range of new technologies that will change the way we do things including auditing. This is on the premise that we are in the advent of artificial intelligence, robotic nanotechnology and quantum computing. In these technological changes, the auditors are not left out, and there will be a need for diversity in the accounting profession. The new technological tools have the potential to enable the auditor mine and analyse a large volume of data related to a company's financial information. This will access $100 \%$ of data as sampling transactions will no longer be relevant. This reaffirmed that the use of these technological tools and method would remain a challenge.

Haislip, Peters and Richardson (2016) posited the dawn of large-scale use of computers in processing, not only accounting information but also numerous other dealings with direct financial implications create a challenge to auditing because large volumes are processed in a short time. The explosion of platforms and software makes it possible to perpetrate frauds in modern ways. Detailed knowledge of information technology and the commitment of highly skilled professionals are essential as more significant audit firm information technology expertise promotes improved internal controls for their clients. Hence, Wen-Hsien et al. (2017) submitted that the internal control environments are positively related to internal audit performance and that companies needed to enhance their internal auditors' information technology competence.

ACFE (2010) affirmed that, in the minds of the investing public, accounting and auditing profession is connected with fraud deterrence, fraud detection and fraud investigation. In this era of technological advancement and the peak that fraud has grown to, the accounting and auditing profession cannot single-handedly deal with the challenges. To contribute to these on-going debates, this study proposed the hypotheses that:

$\mathbf{H}_{01}$ : Electronic-auditing by internal auditors has no significant effect on the economic value of listed companies in Nigeria.

\section{METHODOLOGY}

The study adopted a survey research design. The population of the study consisted of 24 companies selected from the eleven industrial sub-sectors (Agriculture, Conglomerates, Construction, Consumer goods, financial services, Services, Health Care, ICT, Industrial goods, Natural Resources and Oil and Gas sectors) of the 161 listed companies on the Nigerian Stock Exchange as at 30 November 2019. The sample frame of this study is 5012, and the sample size of 501 (comprising 401 internal auditors and 100 top management staff) representing $10 \%$ of the population. This is in line with Agbonifoh and Yomere, (1999), which recommended $10 \%$ of the sample frame as the sample size in order to minimise standard error of the study. Random sampling technique was adopted in the selection of the 24 companies with each chosen company representing each sector. A structured questionnaire with a five-point Likert - scale was administered, and $78.443 \%$ response rate was achieved. The Cronbach alpha reliability coefficients for the constructs were electronic auditing (0.708) and economic value (0.765). The data were analysed utilising descriptive and inferential statistics through IBM Statistical Package for Social Sciences (IBM SPSS version 23.0). 


\section{Model Specification}

To facilitate the analysis of data, the study formulated the following regression model:

$$
E V=\beta_{0}+\beta_{1} E A+\mu_{i t}
$$

Where:

$$
\begin{aligned}
& \text { EV }=\text { Economic Value } \\
& \text { EA }=\text { Electronic-Auditing } \\
& \mu_{\text {it }}=\text { Error Term }
\end{aligned}
$$

\section{ANALYSIS, RESULTS AND DISCUSSIONS}

The study employed a simple regression analysis using the SPSS version 23 Software. The simple regression technique possesses the unique property of best linear unbiased estimator and the desirable qualities of consistency and efficiency.

Table 1. Simple Regression Analysis on the Effect of the Independent Variables on Economic value

\begin{tabular}{|l|l|l|l|l|}
\hline Economic Value & Coefficient & Std. Error & t-Statistics & Prob. \\
\hline Variable & 1.893 & .338 & .599 & .000 \\
C (Constant & .270 & .061 & 4.396 & .000 \\
Electronic auditing & .173 & & \\
\hline R-Squared & .167 & & \\
Adjusted R Square & 27.215 & & \\
F-Statistic & .000 & & \\
Prob. (F-Statistics) & 393 & & \\
Observation & Dependent Variable: Economic Value & & \\
\hline
\end{tabular}

From table 1, we can express the model as follows:

$$
\begin{aligned}
& E V=\beta_{0}+\beta_{1} E A+\mu_{i t} \\
& E V=1.893+0.270 E A+\mu_{i t}
\end{aligned}
$$

From the results of the regression, the constant parameter $\beta_{0}$ is positive at +1.893 . This means that if all the independent variables are held constant, economic value as the dependent variable will increase by 1.893 units in annual-wide basis. Electronic auditing by internal auditor has a coefficient of 0.270 with the corresponding probability value of 0.000 , which means that electronic auditing has a positive and significant effect on economic value. The implication is that a unit increase in electronic auditing by the internal auditor will cause an economic value to increase by 0.270 units.

The $\mathrm{R}^{2}$ is 0.173 . This means that $17.3 \%$ of the variation in economic value is explained by electronic auditing in the listed companies in Nigeria. This indicates the current state of electronic auditing by internal auditors. Also, the t-statistic of 4.396 values expressed that the standard error associated with the parameter showed a lesser effect than the meter itself. Therefore, the null hypothesis of this study which states that electronicauditing by internal auditors has no significant effect on the economic value of listed companies in Nigeria was rejected. It implies that there is a significant effect of electronic auditing by internal auditors on the economic value of listed companies in Nigeria. 


\subsection{Discussion of Findings}

The result in Table 1 shows $R^{2}=.173$ and $t(4.396) ; p<.05$. This result of the regression indicates that electronic auditing by internal auditors has a positive and significant effect on the economic value of listed companies in Nigeria. However, the $\mathrm{R}^{2}$ implies that only $17.3 \%$ of the variation in economic value is explained by electronic auditing, meaning the current level of electronic auditing in listed companies in Nigeria. This implies that many other factors aside electronic auditing affects the economic value of an entity. This result appears to confirm the submission that internal control environments are positively related to internal audit performance and that companies needed to enhance their internal auditors' information technology competence documented by Wen-Hsien, HuiChiao, Jui-Chu and Hsiu-Li (2017).

Haislip, Peters and Richardson (2016) also affirmed that there is a positive association between firms that report information technology (IT) material weaknesses and subsequent auditor dismissal or switching. Our finding also aligns with the study of Moorty, Seetharaman, Mohamed, Gopalan and San (2011) which documented the increasing dependence of organisations on technology to accomplish and support virtually all auditing activities. The study supported the view that business operation in the recent times is such that computers and networks provide most of the information needed for auditing and for an auditor to be effective, they must be able to use a computer as an auditing tool. Organisations operate automated systems, and the internal auditor must understand the business environment in which they operate because automated tools allow auditors to increase individual productivity and that of the audit function (Moorty, Seetharaman, Mohamed, Gopalan \& San, 2011).

The current dynamic business environment and the emerging technologies requirement could pose a challenge to service delivery by professionals such as internal auditors especially as aggravated by the coronavirus pandemic. This is in agreement with Dzuranin and Malaescu (2016) and Barac et al. (2016) on the future direction of information technology in the bid to improve the value of audit practice in emerging technology.

\section{CONCLUSION AND RECOMMENDATIONS}

This study investigated electronic auditing by an internal auditor for the improved economic value of listed companies in Nigeria. The study employed a simple regression technique using the IBM SPSS version 23 for data analysis. The result of the analysis indicates that electronic auditing affects the economic value of listed companies in Nigeria.

This implies that internal auditors must acquire, as part of their skill set, an adequate level of technological knowledge and align with the global trend in technological advancement in order to improve the economic value of listed companies in Nigeria. Also, management of listed companies in Nigeria should strengthen the internal auditors through regular training and recognise the internal audit function alongside the external auditors as a critical component of good corporate governance that can assist the audit committee and board of directors of organisations in improving the economic value of listed companies in Nigeria. 


\section{REFERENCES}

AbdulGaniyy, A. (2013). Audit practice in global perspective: Present and future challenges. Research Journal of Finance and Accounting, 4(6), 1-5.

AbdurRaheem, L. (2020). A PESTLE analysis of Coronavirus pandemic, coping strategies for entrepreneurs and implications on 10 Post-COVID-19 business in Nigeria. A paper presentation at the Muslim News, Nigeria.

Abiola, J. O. (2014). The impact of information and communication technology on internal auditors' independence: PEST analysis of Nigeria. Journal of Scientific Research and Reports, 3(13), 17381752.

Abu-Musa, A. A. (2018). Information technology and implication for internal auditing: an empirical study on Saudi organisation. Managerial Auditing Journal, 23, 438-466.

Agbonifoh, B. A., \& Yomere, G. O. (1999). Research methodology in the social sciences and education $\left(1^{\text {st }}\right.$ ed), Centerpiece Consultant Nigeria Limited. Benin City, University of Benin Press.

Akinnaso, N. (2019). The effectiveness of the whistle blowing policy in combating corruption in the Nigerian public sector. Global Journal of Arts, Humanities and Social Science, 7(10), 77 -98.

Ali, A. M., Saidin, S. Z., Sahdan, M. H., Rasit, M. H., Rahim, M. S., \& Gloeck, J. D. (2012). Internal audit in the Federal Government Organizations of Malaysia: The good, the bad and the very ugly? Asian Journal of Business and Governance, Business Administration Section, 2(1), 68-110.

Ali, E. (2013). Internal audit effectiveness: An approach proposition to develop a theoretical framework. Research Journal of Finance and Accounting, 4(10), 92-102.

Association of Certifed Fraud Examiner (Ratley, J. D. 2010). Report to the nations on occupational fraud and abuse: cases of fraud in higher education. Retrieved May 15, 2018, from http/www.ACFE.com/fraudexaminer.Aspx/id

Barac, K., Gammie, E., Howieson, B., Van-Staden, M., (2016). The capability and competency requirements of auditors in today's complex global business environment. (1st ed.),Edinburgb, Scotland : ICAS

Boynton, W., Johnson, R. \& Kell, W. (2006). Assurance and the integrity of financial reporting (8th ed.). New York: John Wiley \& Son, Inc.

Carmichael, D. R. (2004). The PCAOB and the social responsibility of the auditor. Accounting Horizon, 18(2), 127-133.

Dhumal, S. P. (2015). E-governance-an Application of Information and Communication Technology. International Journal of Engineering Research and General Science, 3(2), 648.

Dibia, N. O. (2016). Perspectives on the internal audit function. Igbinedion University Journal of Accounting, 1(1), 76-86.

Dzuranin, A. C., \& Malaescu, I. (2016). The current state and future direction for information technology audit: challenge and opportunities. American Accounting Association Journal of Information System, 30(1), 7-20.

Ejoh, N. O., \& Ejom, P. E. (2014). The effect of internal audit function on the financial performance of tertiary institutions in Nigeria. International Journal of Economics, Commerce and Management, 2(10), 1-14.

Ferdinand, A. G., \& Mahzan, N. (2013). Auditing: Theory and practice in Malaysia tax and accounting series. Malaysia, $\mathrm{CCH}$ Asia Pte Limited.

Flint, D. (1980). An essay in audit theory - the formulation of basic postulates. An unpublished working paper for the Third Annual Congress of the European Accounting Association.

Haislip, J. Z., Peters, G. F., \& Richardson, V. J. (2016). The effect of auditor IT expertise on internal controls. International Journal of Accounting Information System. Elsevier, 20(C), 1-15.

Hickman, A. (2017). The importance of soft skills for internal auditing. The Journal of the Global Accounting Alliance. American Institute of Certified Public Accountant. Retrieved http://www.gaaaccounting.com/the-importance-of-soft-skills-for-internal-auditors in November 2017.

Institute of Internal Auditors IIA. (2000). Internal Auditing: Adding Value across the Board. Corporate brochure, IIA (ed.) USA.

Izhar, U. D., Xue, M., Ali .S., Shah., \& Ilyas, A. (2017). Role of Information and Communication Technology (ICT) and E-governance in Health sector of Pakistan: A case study of Peshawar. Journal of Cogent Social Sciences, 3(1), 1421010

Lary, A. K., \& Taylor, D. W. (2012). Governance characteristics and role of the effectiveness of the audit committee. Managerial Auditing Journal, 27(4), 336-354.

Limberg Institute. (1932;1985). The social responsibility of the auditor. A basic theory on the auditors' functions, by Professor Theodore Limperg (1870-1961) of the University of Amsterdam (1985 ed.). Amsterdam, The Netherlands: Limperg Institute.

Moorthy, M. K., Seetharaman, A., Mohamed, Z., Gopalan, M., \& San, L. H. (2011). The Impact of information technology on internal auditing. African Journal of Business Management, 5(9), 3523-3539.

Ngoepe, M. (2014). The role of records management as a tool to identify risk in the public sector in South Africa. Journal of Information Management, 16(1), 1-8. 
Nwosu, M. E. (2016). Changes and Challenges of Auditing in the 21st Century: The Nigerian Experience. International Journal of Finance and Accounting, 5(1), 37-45.

Obert, S., \& Munyunguma, I. N. (2014). Internal audit perceptions and their impact on the performance of the internal audit function. Journal of Business and Management, 18(5), 81-85.

Onoja, E., \& Haruna, U. (2015). Internal audit techniques and fraud prevention: a case study of selected local government councils in Bauchi State. Mediterranean Journal of Social Science, 6(4), 232 - 244.

Onuigbo, R., \& Eme, O. I. (2015). Electronic Governance and Administration in Nigeria: Prospects and Challenges. Arabian Journal of Business and Management Review, 5(3), 18-26.

Pathan, S. (2009). Strong boards, CEO power and bank risk-taking. Journal of Banking and Finance, 33(7), $1340-1350$.

Peltier-Rivest, D., \& Lanoue, N. (2015). Cutting fraud losses in Canadian organisations. Journal of Financial Crime, 22(3), 295-304.

Petrascu, D., \& Tieanu, A., (2014). The role of internal audit in fraud prevention and detection. Procedia Economics and Finance, 16, $489-497$.

Salehi, M., \& Alipour, M. (2010). E-Banking in an emerging economy: empirical evidence of Iran. International Journal of Economics and Finance, 2(1), 201-209.

Salehi, M., \& Husini, R. (2011). A study of the effect of information technology on internal auditing: some Iranian evidence. African Journal of Business Management, 5(15), 6169-6179.

Schwab, K. (2016). The fourth Industrial Revolution: what it means, how to respond. A presentation at the World Economic Forum, Korea.

Shahimi, S., Mahzan, N. D., \& Zuikifli, N. (2016). Value-added services of internal auditors: An exploratory study on consulting role in the Malaysian environment. International Journal of Financial Crime, 7(1), 720-735.

Unegbu, A. O., \& Kida, M. I. (2011). Effectiveness of internal audit as an instrument for improving public sector management. Journal of Emerging Trends in Economics and Management Sciences, 2(4), 304309.

Wen-Hsien, T., Hui-Chiao, C., Jui-Chu, C., \& Hsiu-Li, L. (2017). The internal audit performance: the effectiveness of ERM and IT environment. Proceedings of the 50th Hawaii International Conference on System Science, 4898-4906. 